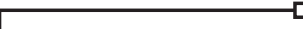

口-

Обтрунтовано використання залізорудного пилу для виготовлення електромагнітних екранів. Розроблено технологію виготовлення екранів. Збільшення дисперсності частинок до 20 разів підвищуе коефіцієнт екранування поля надвисокої иастоти у 8 разів. Коефіцієнт відбиття знижується до 0,10. Коефічієнт екранування магнітного поля промислової частоти за вмісту екрануючої субстанцї $12 \%$ становить 2,2. Визначені електрофізичні властивості екрана

Ключові слова: електромагнітний екран, залізорудний пил, коефічієнт екранування, коефіиієнт відбиття, електрофізичні властивості

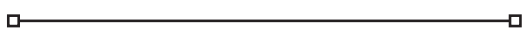

Обосновано использование железорудной пыли для изготовления электромагнитных экранов. Разработана технология изготовления экранов. Увеличение дисперсности частии, до 20 раз повымает коэффициент экранирования поля сверхвысокой частоты в 8 раз. Коэффициент отражения снижается до 0,10. Коэффициент экранирования магнитного поля промыиленной частоты при содержании әкранирующей субстанции $12 \%$ составляет 2,2. Определены электрофизические свойства экрана

Ключевые слова: электромагнитный экран, железорудная пыль, коэффициент экранирования, коэффищиент отражения, электрофизические свойства

\section{DESIGN AND STUDY OF PROTECTIVE PROPERTIES OF ELECTROMAGNETIC SCREENS BASED ON IRON ORE DUST}

V. GI y v a

Doctor of Technical Sciences, Associate Professor, Head of Department

Department of life safety*

S. Podkopa ev

Doctor of Technical Sciences, Professor

Donetsk National Technical University

Shibankova sq., 2, Pokrovsk, Ukraine, 85300

L. Le v che n k o

$\mathrm{PhD}$, Associate Professor**

E-mail: larlevch@ukr.net

N. Karaieva

$\mathrm{PhD}$, Associate Professor**

K. Nikolaiev

$\mathrm{PhD}$, Deputy Director

Educational-Scientific Institute of Ecological Safety*

O. Tyk he n k o

$\mathrm{PhD}$, Associate Professor

Department of Ecology*

O. Khodakovsky y

$\mathrm{PhD}$, Associate Professor

Department of Life Safety at Sea

Kherson State Maritime Academy

Ushakova ave., 19/2, Kherson, Ukraine, 73000

B. K h a I m u r a d ov

$\mathrm{PhD}$, Associate Professor

Department of Civil and Industrial Safety*

* National Aviation University

Kosmonavta Komarova ave., 1, Kyiv, Ukraine, 03058

**Department of Automation of designing of energy processes and systems

National Technical University of Ukraine «lgor Sikorsky Kyiv Polytechnic Institute» Peremohy ave., 37, Kyiv, Ukraine, 03056

\section{Introduction}

Development of technologies for the design, production and operation of electric and electronic equipment can increase its productivity and reduce energy consumption. Along with this, using modern equipment gives rise to changes in the electromagnetic situation in the production environment and general environment. This happens due to expansion of a frequency spectrum of electromagnetic fields of a complex of technical means, a growth of amplitudes of electric and magnetic components of harmonics of electromagnetic field of industrial frequency. All the above requires development and implementation of modern measures and means of protection of people from the influence of electromagnetic fields under production and living conditions. This corresponds to the Ukraine 2020 Strategy for Sustainable Development and represents one of the objectives of the Strategy [1]. 
Screening of electromagnetic fields is an actual problem of health protection, information security, electromagnetic compatibility and electromagnetic environment of residential premises, of protection of premises for servers and other electronic equipment. A fast development of mobile communication, the Internet, an increase in the number of electrical networks increases environmental pollution significantly. Electric transport, household appliances, computer networks also make a significant contribution to environmental pollution. Electromagnetic fields cause errors in the work of IT equipment more and more often, affect a quality of communication. However, there are special tools that use side electromagnetic radiations of electronic devices. Such tools make it possible to:

- take confidential information from servers;

- interfere in a work of information systems;

- listen to negotiations;

- destroy data on electronic media intentionally or by negligence.

Materials for screening of electromagnetic fields recommended by national regulations (electrotechnical steels, permalloys, aluminum and copper alloys), have disadvantages: magnetization of solid ferromagnetic materials in an external magnetic field and high reflective properties of all metallic materials.

The most promising protective materials are composite metal-polymer materials, but most of developments used model materials that are unsuitable for practical use. Therefore, the tasks of development of technologies for production and researching protective properties of low-cost composite materials suitable for covering surfaces of large areas with acceptable screening coefficients are relevant.

\section{Literature review and problem statement}

There are lots of research and applied developments devoted to the elaboration of modern materials for screening of electromagnetic fields and for the production of screens of various designs, because of the need for easy-to-use, flexible, thin, cheap and effective means of protection of people and equipment from electromagnetic influences.

Work [2] presents development and study of properties of electromagnetic screens based on ferromagnets, but most of screening coefficients of the products exist due to reflection of electromagnetic waves, which may worsen the electromagnetic environment outside an area they protect. In this case, their own actual magnetization can increase a level of magnetic fields of ultra-low frequency. Study [3] addresses protection against high-power electromagnetic radiation of radars and has a special purpose.

Developments of narrow application are quite common. Thus, work [4] presents development and research of protective properties of materials for reducing levels of electromagnetic fields of computer equipment. And research [5] - for protection against effects of radiation of mobile phones.

A considerable amount of research and developments consider metal-polymeric protective materials based on finely dispersed metal particles. But such materials are of great value because of complexity of the technology of obtaining nanoparticles of metal particles, which are placed then in a polymer matrix [6]. The same relates to applied work [7]. A complex process of screen production makes producing of materials for large areas very expensive.
Paper [8] presents technology for obtaining nanoparticles by direct synthesis during polymerization, but it is almost impossible to produce a large area of protective material in this way.

Many studies relate to protective materials for screening of an electromagnetic field of a wide range. But they are either metastable due to moisture content [9], or very bulky [10], which complicates their practical use.

It is possible to reduce material costs and simplify production technology by a use of industrial waste as a screening filler. Paper [10] presents results of the development, production and testing of protective properties of electromagnetic screens based on pig iron production waste. Acceptable particle sizes for screening are 5-30 $\mu \mathrm{m}$. However, the content of such particles is small in the waste $\left(\mathrm{Fe}_{2} \mathrm{O}_{3}\right.$ - up to $11.5 \%, \mathrm{FeO}$ - up to $\left.4.5 \%\right)$. Therefore, it is necessary to construct a wedge-shaped form to provide a screening coefficient of $10 \mathrm{~dB}$. This increases thickness of a screen and makes it unfit for covering of surfaces of premises of any purpose.

At the same time, reflection coefficients are up to $3 \mathrm{~dB}$. However, the developed screens are for ultrahigh and highest frequencies, so such screens worsen the electromagnetic environment in reflection directions up to $40 \%$.

Work [11] considers reliability and prevention of degradation of protective material mainly.

Study [12] shows that screening coefficients increase, while reflection coefficients reduce, with decrease in sizes of metal and metal-containing particles in a polymer matrix. A content of nanosized particles in the range of $11-12 \%$ (by weight) provides screening coefficients up to $10 \mathrm{~dB}$ and reflection coefficients up to 0.3 . Increase in dispersion of particles by 2-4 times reduces reflection coefficients by $0.15-0.20$, which is especially important for protection against high-frequency radiations. At the same time, screening coefficients make up $7-8 \mathrm{~dB}$. The thickness of a screen was $5 \mathrm{~mm}$. The above shows that a use of nanoparticles of a metal substance can reduce levels of electromagnetic radiations by $8-10$ times. The experience of field measurements shows that levels of electromagnetic radiations almost never exceed the maximum permissible levels more than 3-4 times during exploitation of powerful electrical equipment and radio engineering objects of civil aviation.

Therefore, it is advisable to use metal and metal-containing particles of a larger size, which are waste of manufacturing processes, for production of protective materials. Paper [13] proposes production of metal-polymer material based on fine dispersed iron ore dust. The paper shows that the content of $\mathrm{Fe}$ and $\mathrm{FeO}$ in it is up to $57 \%$ and $15 \%$, respectively. In this case, dispersion of dust depending on a place of its selection in the aspiration system makes up from 2.5 to $60 \mu \mathrm{m}$. Developers use a matrix of polyvinyl acetate for production of screens of such substance. Screening coefficients of such screens with $10 \%$ content of metallic substance make up $2-5$, and reflection coefficients are $0.2-0.5$. But results presented in papers $[12,13]$ refer to electromagnetic screens made on the basis of model polymers that are not adapted for a use in real production and living conditions. Thus, the problem is the creation of technology for development and research of protective properties of screening metal-polymer material, designed based on reasonable safety adequacy, manufacturability and economic expediency of implementation. 


\section{The aim and objectives of the study}

The aim of present study is the development and production of composite metal-polymer material made on the basis of iron-ore dust for screening of electromagnetic fields of the most critical frequencies.

We determined the following tasks to achieve the objectives:

- investigation of dispersion of dust formed during enrichment of iron ore. Development of a technology for production of material for screening of electromagnetic fields;

- investigation of protective properties of electromagnetic screens in the range of ultrahigh frequencies and protective properties in relation to magnetic fields of the industrial frequency;

- determination of electrophysical and magnetic properties of materials and possibility of their use for forecasting of protective properties of screens;

- conduction of metallographic research on surface and internal layers of the received materials, determination of ways to improve the developed technology.

\section{Methods and methodology of study into protective properties of electromagnetic screens}

We determined dispersion of metal and metal-containing particles of iron ore dust by the sedimentation method with a use of torsion scales. The method makes it possible to determine the granulometric distribution of particles the size of $10^{-7}-10^{-4}$.

We used P3-50 assertive electric and magnetic field tension meter of the industrial frequency (Russian Federation) according to operation manual for the measurement of values of a magnetic field of the industrial frequency.

We used P3-41 device (Russian Federation) according to the operation manual to measure energy flow densities of high-frequency sources. The device also makes it possible to measure an integral value of energy flow density at a desired location of the frequency range of $0.3-30 \mathrm{GHz}$, which is required under the influence of many high-frequency sources of electromagnetic radiations.

We made geometrically closed screens in the form of a cylinder to determine coefficients of screening by protective mater ials of magnetic fields of ultralow frequencies. We placed the measuring antenna inside the screen through a technology hole, which was closed firmly. The necessity of a use of a solid screen is due to quasi-stationarity of ultralow frequency magnetic fields. This makes it impossible to penetrate a magnetic field outside the screen. The screening coefficient is the ratio of the intensity of the magnetic field outside the screen to this indicator inside the screen.

In general, a size of such a screen may affect measurement results in the case it is made of a ferromagnetic material due to magnetization in an external magnetic field. But tests showed that the use of iron and its oxides in the production of a screen in small quantities (up to $15 \%$ by weight) has little effect and does not exceed the measurement equipment error.

We carried out determination of screening coefficients of el e ctromagnetic radiations of ultrahigh frequencies as follows. We made electromagnetic screens the size of $0.75 \times 0.75 \mathrm{~m}$. We placed them to a cut of the corresponding form in a metal sheet, which ensured inability of radia- tion penetration outside the screen. We located the screen betwe e $n$ the source of electromagnetic radiation and the measu $r$ ing antenna. Measurement error did not exceed $20 \%$, either.

It is mandatory to determine contribution, which occurs due to reflection of electromagnetic waves, to the overall screening coefficient for development of means of protection against the influence of electromagnetic radiation of ultrahigh and highest frequencies.

We car ried out measurement of this parameter without a use of an insulating metal sheet with a slit for the screen due to high reflective properties of metal materials. We performed measurements in three stages. Initially, we measured the energy flow density for a fixed distance of a radiation source. Then we measured this value using an electromagnetic screen. We located the measuring antenna at a distance of $0.2 \mathrm{~m}$ behind the screen. The next measurement - with antenna placement at a distance of $0.2 \mathrm{~m}$ in front of the screen.

A back ground of external magnetic and electromagnetic fields was within sensitivity of devices during all experiments.

We carried out metallographic studies using the MIM-8 metallographic microscope (Ukraine). We determined location of metal particles in the material by the method of selective etching in a $20 \%$ solution of nitric acid at a temperature of $20-30{ }^{\circ} \mathrm{C}$ for $10-20$ minutes.

\section{Technology of production of electromagnetic screens based on iron ore dust and foam-latex}

All $\mathrm{m}$ e tal-polymer protective materials consist of a screening filler and a polymer matrix. We selected iron ore dust as a filler. The chemical composition of dust, which moves through aspiration systems at the Kryvy Rih Mining and Processing Plant (Ukraine), is known, and we determined the dispersion experimentally (Table 1 ).

Table 1

Chemical composition and dispersion of particles, which move through pipelines of aspiration systems *

\begin{tabular}{|c|c|c|}
\hline Aspiration system & $\begin{array}{c}\text { Quantitative } \\
\text { composition, \% }\end{array}$ & $\begin{array}{l}\text { Dispersion } \\
\text { composition, \% }\end{array}$ \\
\hline $\begin{array}{l}\text { Aspiration system of } \\
\text { quenching drums }\end{array}$ & $\begin{array}{c}\mathrm{Fe}-43 \\
\mathrm{FeO}-8 \\
\mathrm{CaO}-15\end{array}$ & $\begin{array}{l}\text { Less than } 5 \mu \mathrm{m}-48 \\
\quad 5-10 \mu \mathrm{m}-21 \\
20-50 \mu \mathrm{m}-8 \\
\text { Larger than } 50 \mu \mathrm{m}-10\end{array}$ \\
\hline Reloading unit & $\begin{array}{l}\mathrm{Fe}-58 \\
\mathrm{FeO}-15 \\
\mathrm{CaO}-10\end{array}$ & $\begin{array}{c}\text { Less than } 5 \mu \mathrm{m}-52 \\
5-10 \mu \mathrm{m}-14 \\
15-20 \mu \mathrm{m}-15 \\
\text { Larger than } 25 \mu \mathrm{m}-11\end{array}$ \\
\hline $\begin{array}{l}\text { Sizing, grinding and } \\
\text { cooling agglomerate }\end{array}$ & $\begin{array}{c}\mathrm{Fe}-57 \\
\mathrm{FeO}-15 \\
\mathrm{CaO}-10\end{array}$ & $\begin{array}{c}5 \mu \mathrm{m}-21 \\
5-10 \mu \mathrm{m}-16 \\
10-15 \mu \mathrm{m}-8 \\
15-50 \mu \mathrm{m}-6 \\
200-500 \mu \mathrm{m}-11\end{array}$ \\
\hline
\end{tabular}

Note: * - Data on metal and metal-containing particles that provide screening of an electromagnetic field are given

Fiber filters absorb dust. Particles of larger sizes stay on first curtains at the use of a six-row fiber filter, smaller ones - on the last curtains (Table 2). 
Table 2

Fractional efficiency of a six-row fiber filter

\begin{tabular}{|c|c|c|c|c|c|c|c|}
\hline $\begin{array}{c}\text { Size of } \\
\text { particles, } \\
\mu \mathrm{m}\end{array}$ & $<2.5$ & $\begin{array}{c}2.5- \\
6.3\end{array}$ & $6.3-10$ & $10-16$ & $16-25$ & $25-50$ & $50-63$ \\
\hline $\begin{array}{c}\text { Fraction } \\
\text { efficiency, } \\
1 \%\end{array}$ & 48.40 & 89.38 & 98.90 & 99.50 & 99.80 & 99.90 & 99.95 \\
\hline
\end{tabular}

The given data make it possible to choose metal and metalcontaining substances of known composition and the required dispersion for production of electromagnetic screens.

We selected metal and metal-containing dust from 1-2, $3-4$ and 5-6 curtains of a six-row fiber filter for production of screening material.

After analysis of requirements for the material and a series of tests of various materials as a basis (matrix) of future electromagnetic screens, we decided to choose a composite material, which has a foam-latex as its base.

The technology of foam-latex production is known and widespread. We changed the technology partially to provide foam-latex with properties of electromagnetic screens. We added iron ore dust to a standard mixture before grinding of standard components of foam-latex in a special mill - in a brabender. We used dust with dispersions of 5-10 $\mu \mathrm{m}$, $15-25 \mu \mathrm{m}, 50-100 \mu \mathrm{m}$ for this purpose. Weighing dust amounts made up 1-15\%. We obtained the final material by squeezing of a liquid polymer through a rectangular hole on a rolling press. We carried out a heat treatment of the material with surface vulcanization on a rolling press. A distance between rollers was $5 \mathrm{~mm}$, which corresponds to the final thickness of the material. The thickness of vulcanized layer was $1.0-1.5 \mathrm{~mm}$.

\section{Study into protective properties of metal-polymer electromagnetic screens}

We carried out testing of protective properties in two series - on the electromagnetic field of ultrahigh frequency and the magnetic field of industrial frequency.

Frequency of screened electromagnetic field was $1.8 \mathrm{GHz}$. We chose the frequency based on its largest use in wireless media now.

Fig. 1 shows the dependence of a screening coefficient on the weight content of the screening material.

For high-frequency electromagnetic fields, it is important to determine contribution of screening by reflection of electromagnetic waves of a small length, that is, a reflection coefficient, to the overall screening coefficient. This is due to possibility of reflection of radiation to an undesirable side, that is, deterioration of the electromagnetic environment outside a zone protected by a screen. Fig. 2 shows the dependence of the reflection coefficient on the same parameters.

An analysis of results shows that increase in dispersion of a screening substance by 2-3 times guarantees an increase in a screening coefficient by 2 times. At the same time, a coefficient of reflection reduces significantly (to 0.1 ). We should note that even with the use of large metal and metal-containing particles, screening coefficients are high at sufficient concentrations (14-15\%). However, a reflection coefficient is close to a rate of metal materials, so it is already unacceptable for a use for protective covering of large areas.
$\boldsymbol{K}_{s}$

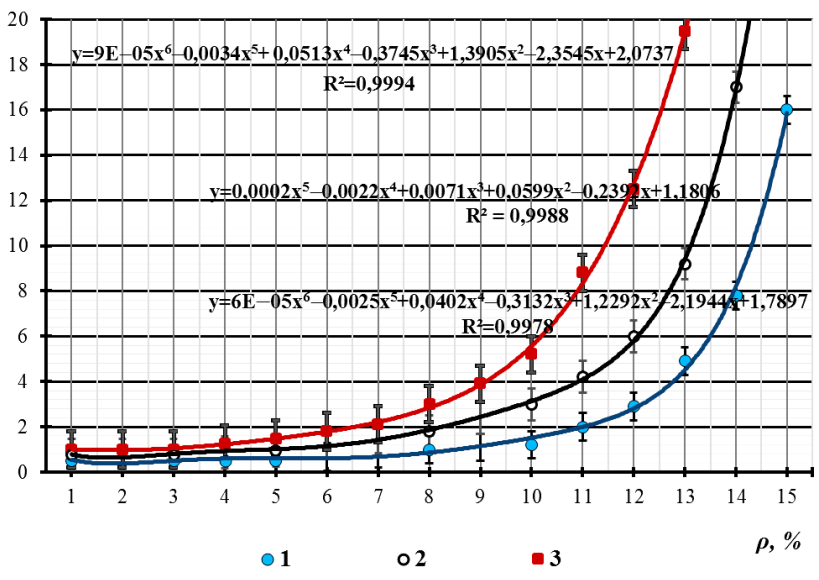

Fig. 1. Dependence of a screening coefficient $\left(K_{s}\right)$ of metal-polymer material on a content $(\rho)$ and dispersion of a screening substance:

- $-50-100 \mu \mathrm{m}, \mathrm{o}-15-25 \mu \mathrm{m},-5-10 \mu \mathrm{m}$

$\boldsymbol{K}_{\boldsymbol{r}}$

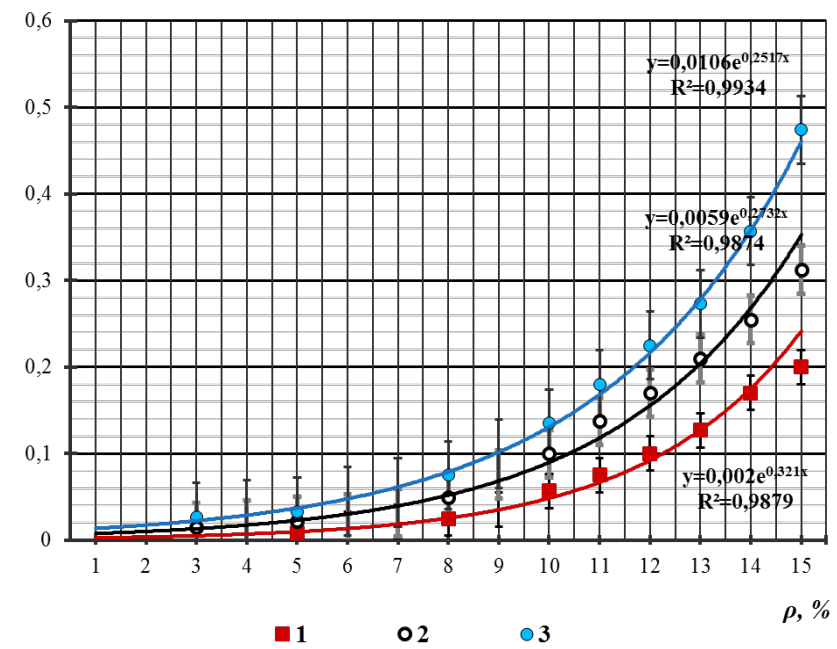

Fig. 2. Dependence of reflection coefficient $\left(K_{r}\right)$ of electromagnetic waves of metal-polymer material on a content $(\rho)$ and dispersion of a screening substance

$\bullet-50-100 \mu \mathrm{m}, 0-15-25 \mu \mathrm{m},-5-10 \mu \mathrm{m}$

We built geometrically closed constructions of the investigated materials to determine screening efficiency of a magnetic component of the electromagnetic field at an industrial frequency of $50 \mathrm{~Hz}$. There is no sense in measurement of a reflection coefficient taking into account the quasi-stationary nature of such a field.

Fig. 3 shows test results.

The above shows that the developed screen makes possible to reduce levels of magnetic fields of ultralow frequencies by twice by the content of the filler by $12 \%$.

We performed determination of the specific conductivity of the material by measuring an inverse value - specific resistance by the method of doubled bridge. Fig. 4 shows results of the study.

We carried out measurements of dielectric conductivity according to the bridge scheme, which made possible to receive a value of the electric capacity from $10 \Omega$ to $10 \mathrm{M} \Omega$ and the active component of the total electrical resistance $(10 \Omega-10 \mathrm{M} \Omega)$ for $\operatorname{tg} \delta \leq 1,000$ separately (Fig. 5). 
$\boldsymbol{K}_{s}$

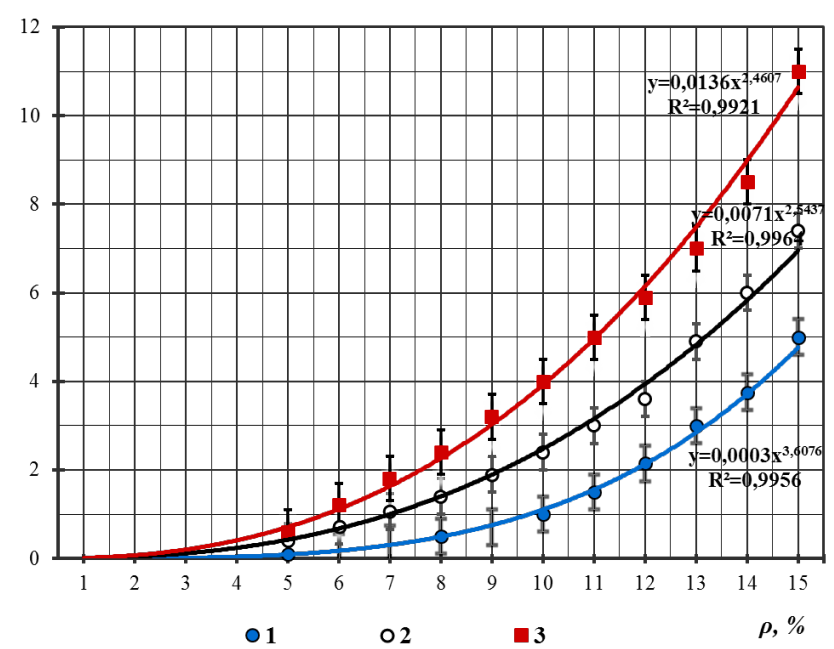

Fig. 3. Dependence of screening coefficient $\left(K_{s}\right)$ of magnetic field of the industrial frequency of $50 \mathrm{~Hz}$ on content $(\rho)$ and dispersion of a metallic substance in a polymer matrix $\bullet-50-100 \mu \mathrm{m}, \circ-15-25 \mu \mathrm{m}, \bullet-5-10 \mu \mathrm{m}$

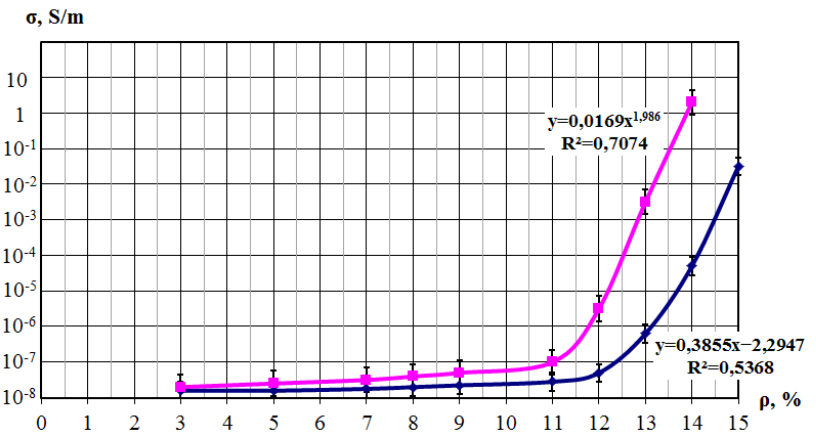

Fig. 4. Dependence of specific conductivity $(\sigma)$ of metalpolymer screens on content $(\rho)$ and dispersion of a screening substance, $=-5-10 \mu \mathrm{m}, \bullet-15-25 \mu \mathrm{m}$

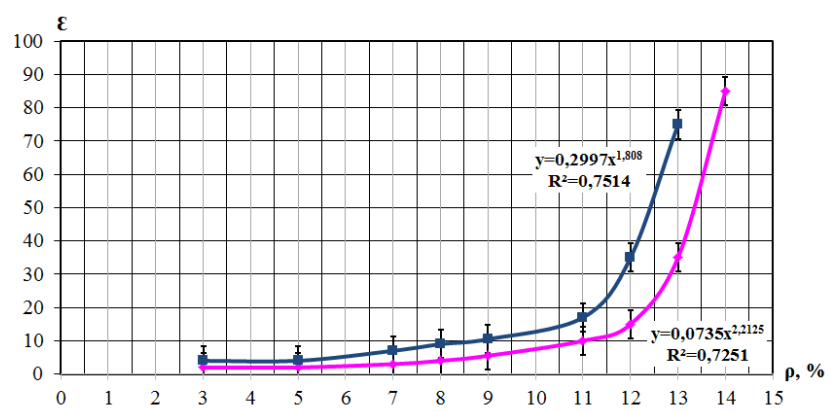

Fig. 5. Dependence of dielectric permeability $(\varepsilon)$ of metal-polymer screens on content $(\rho)$ and dispersion of a screening substance, $\square-5-10 \mu \mathrm{m},-15-25 \mu \mathrm{m}$

The obtained data are the basis for forecasting of the efficiency of electromagnetic screens depending on parameters of an electromagnetic field, which needs to be screened. We can use quantitative values of specific conductivity and relative dielectric permeability to determine complex permeability (real and imaginary components). This is necessary for calculation of absorption and reflection coefficients of electromagnetic waves using a previously developed mathematical apparatus [12].
This significantly simplifies and accelerates implementation of work on development and implementation of organizational and technical measures for electromagnetic security for ultrahigh and higher frequencies.

Information on magnetic permeability of materials is required for calculational forecasting of protective properties of a screen for the screening of a magnetic field of ultralow frequency. Direct determination is complex due to the dependence on density of location of iron and iron-containing particles and complexity of a mixture.

It is advisable to determine this parameter based on experimental data taking into account a functional relationship of these indicators.

Let us consider a cylindrical magnetic screen with an internal radius $a$, an external radius $-b$, which is located in an external quasi-stationary magnetic field with $H_{0}$ intensity (Fig. 6).

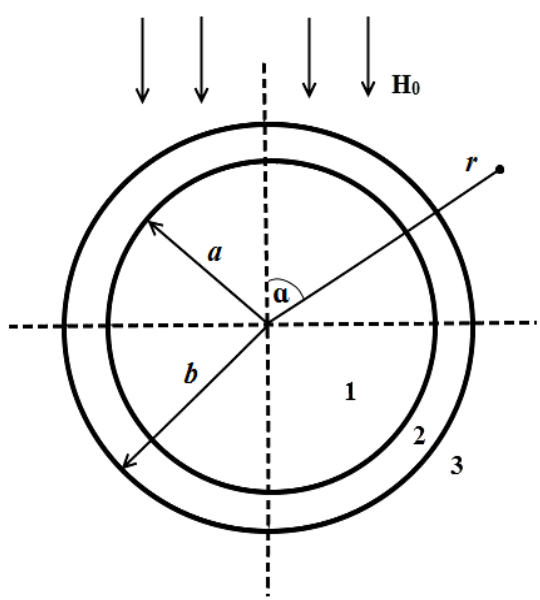

Fig. 6. Scheme for calculation of a screening coefficient of magnetic field of ultralow frequency with a cylindrical screen

We assume that the relative permeability of the screen material is $\mu$. The magnetic permeability outside the screen and inside the screen are equal to one. We consider the cylindrical screen to be long enough along $Z$ axis (perpendicular to the plane of the figure). In the absence of electric current in all three zones $(1,2,3)$, Laplace equation describes the magnetic field in them:

$$
\nabla^{2} \varphi=0,
$$

where $\varphi$ is the scalar magnetic potential.

The value of $\varphi$ depends on coordinates $r$ and cylindrical coordinate system $\alpha$ only. Equation (1) in these coordinates takes the form:

$$
\nabla^{2} \varphi=\frac{1}{r} \cdot \frac{\partial}{\partial r}\left(r \frac{\partial \varphi}{\partial r}\right)+\frac{\partial^{2} \varphi}{r^{2} \partial \alpha^{2}}=0 .
$$

The solution to the equation by a Fourier method produces:

- for the first zone:

$\varphi_{1}=\left(C_{1} r+\frac{C_{2}}{r}\right) \cos \alpha$

- for the second zone: 
$\varphi_{2}=\left(C_{3} r+\frac{C_{4}}{r}\right) \cos \alpha$

- for the third zone:

$\varphi_{3}=\left(C_{5}+\frac{C_{6}}{r}\right) \cos \alpha$

We assume a constant of integration, with the accuracy to which a potential is determined, as a zero.

We construct corresponding equations to determine six constants $\left(C_{1}-C_{6}\right)$.

We compare $\varphi_{3}$ with an expression at an infinite distance $\varphi=H_{0} r \cos a$. This equation gives $C_{5}=H_{0}$.

$\varphi$ must remain finite in zone 1 for $r=0$. This is possible only if there is no $\frac{C_{2}}{r}$. component in the expression. This happens for $C_{2}=0$. Equation $\varphi_{1}$ and $\varphi_{2}$ for $r=a$ gives the equation

$$
C_{1} a=C_{3} a+\frac{C_{4}}{a} .
$$

The condition of continuity of the potential is equivalent to the condition of equality of tangential components of the magnetic field strength at the boundary of the section at $r=a$.

Taking into account that

$$
\vec{H}=-\operatorname{grad} \varphi, \quad H_{\alpha}=-\frac{\partial \varphi}{r \partial \alpha},
$$

SO

$$
H_{\alpha}^{1}=-C_{1} \sin \alpha, H_{\alpha}^{2}=-\sin \alpha\left(C_{3}+\frac{C_{4}}{a^{2}}\right) .
$$

Thus

$$
C_{1}=C_{3}+\frac{C_{4}}{a^{2}}
$$

We can determine the value of $\varphi$ at the boundary of zones 2 and $3(r=b)$ by the equation:

$$
C_{5} b+\frac{C_{6}}{b}=C_{3} b+\frac{C_{4}}{b} \text {. }
$$

Equality of normal components of induction

$$
B_{r}=-\mu_{a} \frac{\partial \varphi}{\partial r}
$$

at the boundary of these zones (for $r=a$ ):

$$
C_{1}=\left(C_{3}-\frac{C_{4}}{a^{2}}\right) \mu,
$$

where $\mu$ is the desired relative permeability of the screen.

We can determine equality of normal components of induction for $r=b$ from equation:

$$
C_{5}-\frac{C_{6}}{b^{2}}=\left(C_{3}-\frac{C_{4}}{b^{2}}\right) \mu .
$$

The joint solution to these two equations yields an expression for the potential in zone 1:

$$
\varphi_{1}=H_{0} \frac{2 q b^{2}}{\Delta} r \cos \alpha
$$

Or, in Cartesian coordinates (axis $x$ directed upward, $x=r \cos \alpha)$ :

$$
\varphi_{1}=H_{0} \frac{2 q b^{2}}{\Delta} x
$$

where

$$
q=\frac{2 \mu}{(1+\mu)^{2}} \approx \frac{2}{\mu} ; \quad \Delta=b^{2}-\beta^{2} a^{2}, \quad \beta=\frac{\mu-1}{\mu+1} \approx 1 .
$$

Magnetic field tension in zone 1:

$$
H_{1}=\frac{\partial \varphi_{1}}{\partial x}=H_{0} \frac{2 q b^{2}}{\Delta} .
$$

The screening coefficient is the ratio of field strength outside the screen and in the zone protected with a screen, therefore

$$
K_{s}=\frac{H_{0}}{H_{1}}=\frac{\Delta}{2 q b^{2}} \approx \frac{\mu\left(b^{2}-a^{2}\right)}{4 b^{2}} .
$$

We calculate effective magnetic permeabilities for different concentrations of the metal substance using the above ratio and experimental data on the screening coefficient (Fig. 3). For particles the size of $5-10 \mu \mathrm{m}$, a change in their content from 7 to $15 \%$ increases their magnetic permeability from 85 to 190 .

Thus, we can determine magnetic permeability of protective materials having experimental data on the screening coefficients. They are the main indicators for calculational forecasting of protective properties of magnetic screens in the low-frequency region of the spectrum.

\section{Discussion of results of study inton protective} properties of electromagnetic screens

The given results lead to the conclusion that electromagnetic screens based on iron ore dust have significant advantages over other metal-polymer protective materials. The presence of products of various and known dispersion gives possibility to produce screens with the necessary protective properties based on the real electromagnetic environment in a screened room or a building in general. It is necessary to synthesize particles or to grind a protective substance to the required dispersion to solve similar problems in another way. The large dependence of screening coefficients (including reflection) on the concentration of metal and metal-containing particles in the body of a polymer matrix makes possible to create screens on the principle of reasonable sufficiency. At the same time, it is possible to ensure a smooth operation of wireless communication facilities at an acceptable degree of electromagnetic security. The material developed with the insignificant cost of used components is suitable for covering surfaces of large areas, which is especially important to reduce the level of the magnetic field of the industrial frequency. The effective magnetic permeability of the material is similar to the specification data on magnetic liquids based on nanoiron, which have an extremely high cost. 
Paper [12] shows that protective properties of a composite material depend not only on its thickness, electrophysical and magnetic properties, but also on uniform distribution of a screening substance in the dielectric matrix. Therefore, we performed metallographic studies of surfaces and inner layers of the materials obtained.

Fig. 7 shows distribution of such particles on a surface of material at different concentrations of metal particles.

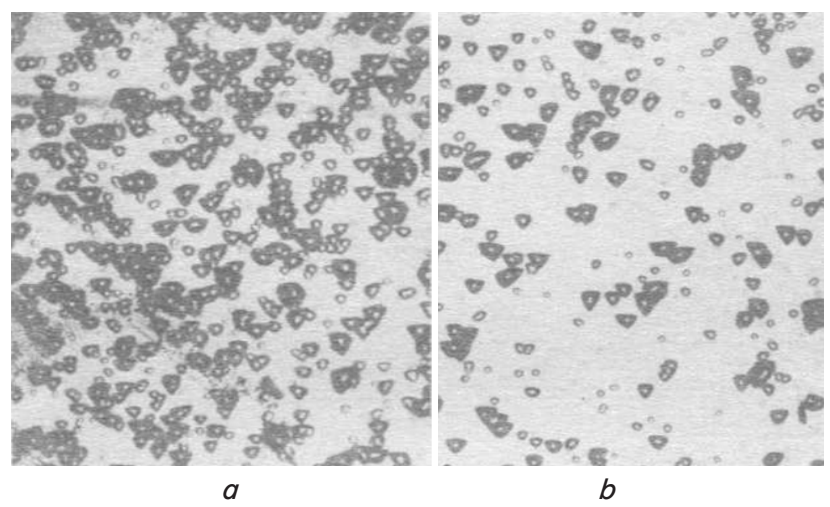

Fig. 7. Distribution of metal particles on a surface of protective material by their weight content: $a-15 \% ; b-7 \%$. Magnification $\times 350$

The above structures show that at least pure metal (iron) particles have a certain tendency to stick together in the process of material producing. Therefore, it is expedient to use special technological solutions in order to increase the uniformity of distribution of metal particles. This is possible due to production of a colloidal solution similar to a magnetic liquid with a use of a surfactant on the basis of iron ore dust.

We also investigated distribution of filler particles on the cross-section of material (Fig. 8).

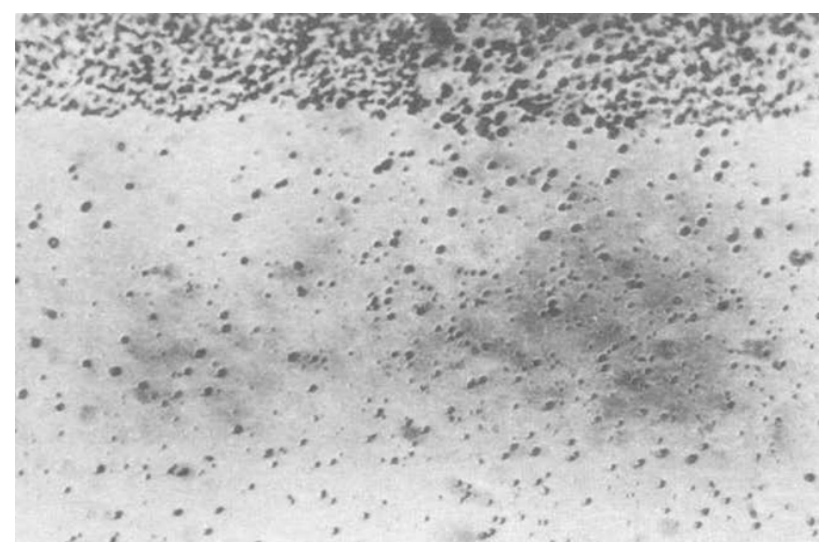

Fig. 8. Distribution of metal particles on the cross-section of protective material. Magnification $\times 250$

Fig. 8 shows that iron ore particles accumulate mainly in the near-surface layer of material. Perhaps this is due to the vulcanization process, but it gives the ability to reduce thickness of protective material at least twice, which simplifies its use for covering surfaces of complex configurations.
Extraordinary elasticity and porosity of foam-latex is able to cover surfaces of complex configurations and contribute to lower levels of acoustic noise, which is a promising area for further research.

The obtained data on electrophysical and magnetic properties of material are sufficient for calculation of forecasting of degrees of protection during development of organizational and technical measures on electromagnetic safety.

\section{Conclusions}

1. High dispersion and chemical composition of iron ore dust give possibility to use it as a screening filler in metal-polymer electromagnetic screens. High dispersion of iron ore particles $(5-100 \mu \mathrm{m})$, which accumulate at individual sections of filtering systems, makes possible to use them in production of screens of the required efficiency. The technology of production of material for screening of electromagnetic fields in the form of foam-latex is able to control protective properties of both by the content of a lead substance and by a use of particles of different dispersion. Vulcanized surfaces of a material with a depth of $1.0-1.5 \mathrm{~mm}$ ensure its strength, hydrophobicity and possibility of covering of surfaces of complex configurations.

2. Tests of the developed materials indicate that the content of metal and metal-containing particles in the polymer matrix is $12 \%$, the coefficient of screening of the electromagnetic field of ultrahigh frequency for particles of $50-100 \mu \mathrm{m}$ is 2.5 with a reflection coefficient of 0.23 . For particles the size of $5-10 \mu \mathrm{m}$, these figures are 12 and 0.1 , respectively. Increase in particle dispersion from $50-100 \mu \mathrm{m}$ to $5-10 \mu \mathrm{m}$ increases the screening coefficient of the magnetic field of an industrial frequency with the same weight content of $12 \%$ from 2 to 6 , which is fully acceptable for most of production conditions.

3. We determined electrophysical properties of the developed protective material (specific conductivity and dielectric permeability). We provided the method for determination of magnetic permeability depending on dispersion and a weight content of a screening substance. The results are the output data for calculational forecasting based on known ratios of protective properties of materials at the stages of design work on electromagnetic safety. The study shows that a sharp increase in specific conductivity from $10^{-7}-10^{-6}$ to $10^{-3}-10^{-2} \mathrm{~S} / \mathrm{m}$ and dielectric permeability from $10-20$ to $70-80$ occurs at the concentration of lead substance of $11-12 \%$. This corresponds to the threshold of electric current and is consistent with the position of the electrodynamics of solid environments.

4. Metallographic studies of distribution of metal particles on a surface and in a body of the material obtained indicate partial adhesion of individual particles. At the same time, these particles are concentrated in a surface layer of material of $1.2-1.5 \mathrm{~mm}$ thickness. This corresponds to the thickness of a vulcanized layer. The above shows possibility of improvement of the material by reducing its thickness and increasing uniform distribution of metal particles by using surface active materials in the technological process.

\section{References}

1. Tsili Staloho Rozvytku: Ukraina. Natsionalna dopovid 2017 // Predstavnytstvo Orhanizatsiyi Obiednanykh Natsiyi v Ukraini. URL: http://www.un.org.ua/ua/tsili-rozvytku-tysiacholittia 
2. Ekrany elektromagnitnogo izlucheniya na osnove magnitnyh materialov. Tekhnologii. Konstrukcii. Primenenie / Bogush V. A., Borbot'ko T. V., Nasonov N. V. et. al. Minsk: Bestprint, 2016. 222 p.

3. An Ultrathin and Broadband Radar Absorber Using Resistive FSS / Li M., Xiao S., Bai Y.-Y., Wang B.-Z. // IEEE Antennas and Wireless Propagation Letters. 2012. Vol. 11. P. 748-751. doi: 10.1109/lawp.2012.2206361

4. Singh J. Computer Generated Energy Effects on Users and Shielding Interference // International Journal of. Innovative Research in Computer and Communication Engineering. 2015. Vol. 3, Issue 10. P. 10022-10027.

5. Kasar V., Pawar A. A Novel Approach to Electromagnetic Interference Shielding for Cell Phones // International Journal of Science and Research. 2014. Vol. 3, Issue 11. P. 1869-1872.

6. Electromagnetic shielding of polymer-matrix composites with metallic nanoparticles / Jalali M., Dauterstedt S., Michaud A., Wuthrich R. // Composites Part B: Engineering. 2011. Vol. 42, Issue 6. P. 1420-1426. doi: 10.1016/j.compositesb.2011.05.018

7. Low percolation threshold and electromagnetic shielding effectiveness of nano-structured carbon based ethylene methyl acrylate nanocomposites / Mondal S., Ganguly S., Das P., Khastgir D., Das N. C. // Composites Part B: Engineering. 2017. Vol. 119. P. 41-56. doi: 10.1016/j.compositesb.2017.03.022

8. Polymer nanocomposites: synthesis and physical properties / Fionov A. S., Yurkov G. Y., Popkov O. V., Kosobudskii I. D., Taratanov N. A., Potemkina O. V. // Advances in Composite Materials or Medicine and Nanotechnology. 2011. P. 343-364.

9. Shirokodiapazonnye konstrukcii ekranov elektromagnitnogo izlucheniya na osnove vlagosoderzhashchey cellyulozy / Al'Ademi Ya. T. A., Ahmed A. A. A., Pulko T. A., Nasonova N. V., Lyn'kov L. N. // Trudy MAI. 2014. Issue 77.

10. Ekran elektromagnitnogo izlucheniya na osnove poroshkoobraznyh othodov proizvodstva chuguna / Boyprav O. V., Borbot'ko T. V., Lin'kov L. M., Sokolov V. B. // Trudy MAI. 2014. Issue 67. P. 3-19.

11. Polyvinylidene fluoride based lightweight and corrosion resistant electromagnetic shielding materials / Bhingardive V., Sharma M., Suwas S., Madras G., Bose S. // RSC Advances. 2015. Vol. 5, Issue 45. P. 35909-35916. doi: 10.1039/c5ra05625j

12. Research into protective properties of electromagnetic screens based on the metal-containing nanostructures / Glyva V., Kovalenko V., Levchenko L., Tykhenko O. // Eastern-European Journal of Enterprise Technologies. 2017. Vol. 3, Issue 12 (87). P. 50-56. doi: 10.15587/1729-4061.2017.103167

13. Doslidzhennia zakhysnykh vlastyvostei elektromahnitnykh ekraniv na osnovi dribnodyspersnoho zaliza ta yoho spoluk / Hlyva V. A., Lapshyn O. Ye., Kovalenko V. V., Khudyk M. V. // Visti Donetskoho hirnychoho instytutu. 2017. Issue 1 (40). P. $123-127$. 